Summer 2006

\title{
The Forgotten Threat: Private Policing and the State
}

Elizabeth E. Joh

University of California, Davis

Follow this and additional works at: https://www.repository.law.indiana.edu/ijgls

Part of the International Law Commons

\section{Recommended Citation}

Joh, Elizabeth E. (2006) "The Forgotten Threat: Private Policing and the State," Indiana Journal of Global Legal Studies: Vol. 13 : Iss. 2 , Article 2.

Available at: https://www.repository.law.indiana.edu/ijgls/vol13/iss2/2

This Article is brought to you for free and open access by the Law School Journals at Digital Repository @ Maurer Law. It has been accepted for inclusion in Indiana Journal of Global Legal Studies by an authorized editor of Digital Repository @ Maurer Law. For more information, please contact rvaughan@indiana.edu.

\section{$\Psi$}

JEROME HALL LAW LIBRARY

INDIANA UNIVERSITY

Maurer School of Law
Blooming ton 


\title{
The Forgotten Threat: Private Policing and the State
}

\author{
Elizabeth E. Joh*
}

\section{Abstract}

What do Disneyland, the Abu Ghraib U.S. military prison, the Mall of America, and the Y-12 nuclear security complex in Oak Ridge, Tennessee have in common? They have wildly different purposes, but they share a common characteristic as employers of private police. This answer-indicative of the prevalence and numbers of private police today-would have struck the nineteenth-century observer as evidence of a gross failure by the state. Yet that reaction, in turn, would seem odd to us. Vocal support of private police can be found among public police chiefs, laumakers, and even President Bush.

What kinds of criticisms were once leveled at private police by public officials? How did one attitude, deeply skeptical of private police, evolve into another that sees heavy reliance upon private policing as beneficial, or at least benign? Here, I take a fresh look at the dynamics of that change, and by doing so, restore to their proper place fundamental questions about the use of police who are privately financed and organized in a democratic society. These questions, and the violent history that midwived them, have been largely and undeservedly forgotten by the legal literature.

Using this historical perspective, I examine the shifting status of private policing: first, by examining the history of public criticism directed against them; second, by recounting the partnership model that first gained a foothold in studies sponsored by the federal government in the 1970; and 1980; and third, by questioning the meaning and intentions behind the idea of partnership advanced today.

*Acting Professor of Law, University of California, Davis (eejoh@ucdavis.edu). Ph.D. 2004, J.D. 2000, New York University; B.A. 1994, Yale University. Thanks to Paul Chevigny, David Garland, Charles Reichmann, and Jerome Skolnick for their comments and suggestions, to the staff of the U.C. Davis Law Library, Erin Murphy, and Rachel Phillips for research assistance, and to Dean Rex Perschbacher, Associate Dean Kevin R. Johnson, and the U.C. Davis Law School for financial assistance and institutional support. 


\section{INTRODUCTION}

God help them tonight in the hour of their affliction

Praying for him who they'll ne'er meet again

Hear the poor orphans tell their sad story

Father was killed by the Pinkerton men.

- William W. Delaney, Father was Killed by the Pinkerton $\mathrm{Men}^{\mathrm{i}}$

Here the basic issue is one of government: May a portion of the police power be sold to a private corporation to be thereafter exercised by its employees for its profit?

- Justice Talbot Smith, Peoplev. Robinson ${ }^{2}$

The moment is at hand for corporate interests and public law enforcement to make a ... gesture and forge a professional bond. Its creation would serve the welfare of all citizens by producing farreaching benefits for American policing.

- Michael G. Shanahan, Private Enterprise and the Public Police: The Professionalizing Effects of a New Partnership ${ }^{3}$

What do Disneyland, the Abu Ghraib U.S. military prison, the Mall of America, and the Y-12 nuclear security complex in Oak Ridge, Tennessee have in common? These places have wildly different purposes (civil defense, recreation) and identities (public, private, or quasi-private). Yet there is a commonality: each employs private police. ${ }^{4}$ Less obvious is that this answer-indicative of the prevalence and numbers of private police today-would have stunned an observer from the vantage point of the late-nineteenth century. Surely, our time traveler would remark, the dominance of private policing represents the failure of the state, and a crisis in public confidence. Yet that reaction would seem odd

1. This was a popular song penned by William Delaney, more commonly known as "Willie Wildwave." See Robert M. La Follette, Strikebreaking Services, S. Rep. No. 76-6, at 14 n.2 (1939).

2. People v. Robinson, 74 N.W.2d 41, 47 (Mich. 1955) (Smith, J., dissenting).

3. Michael G. Shanahan, Private Enterprise and the Public Police: The Professionalizing Effects of a New Partnership, in Police Leadership in America 449, 458 (William A. Geller ed., 1985).

4. See Elizabeth E. Joh, The Paradox of Private Policing, 95 J. CRIm. L. \& Criminology 49, 55 (2004) (defining private policing as the "various lawful forms of organized, for-profit personnel services whose primary objectives include the control of crime, the protection of property and life, and the maintenance of order" (emphasis omitted)). Although I excluded private military companies from my definition in Joh, supra, I begin this article with their inclusion to provide a sense of how prevalent the use of private civil and military police forces has become. 
to our contemporary ears. We live at a time when public police chiefs, legislators, and policymakers openly support reliance on private police and, indeed, encourage public partnerships with them. A presidential initiative even exhorts increased support for private policing as a component of post-9/11 "homeland defense." 5

What kinds of criticisms were once leveled at private police by public officials? How did one attitude, deeply skeptical of the private police, evolve into another that sees private policing as inherently benign? This article takes a fresh look at the dynamics of that change, and by doing so, restores to their proper place fundamental questions about the use of police who are privately financed and organized in a democratic society. These questions, and the violent history that midwived them, have been largely and undeservedly forgotten by the legal literature.

The need for a historical perspective on private policing is more urgent than ever. Private police employment in the United States is greater than it has ever been, ${ }^{6}$ yet critics and supporters alike largely ignore the lessons that the history of private policing has to offer. ${ }^{i}$ Critics raise issues of accountability, and the private usurpation of a government function. Advocates cite the benefits of cheaper, more responsive alternatives to the public police. Yet these issues are not new, and much can be learned from more than a century of experience with private policing.

So too can history show us that the relationship between the state ${ }^{8}$ and private policing is not accurately described as one of intermittent regulation. Whether it encourages by inaction, or discourages through legislation and public critique, the state is always implicated in the development of private polic-

5. The White House, The National Strategy for the Physical Protection of Critical Infrastructures and Key Assers 29 (2003) (identifying "private security officers" as "an important source of protection for critical facilities"), available at http://www.whitehouse.gov/pcipb/ physical_strategy.pdf.

6. Joh, supra note 4, at 55 (observing that there are at least three private guards for every public police officer and that at least twice as much is spent on private policing as is spent on public policing).

7. Two important exceptions are Clifford D. Shearing, The Relation Between Public and Private Policing, 15 Crime \& Just. 399 (1992), reprinted in Modern Policing 399 (Michael Tonry \& Norval Morris eds., 1992), and a discussion in David A. Sklansky, The Private Police, 46 UCLA L. Rev. 1165, 1212-29 (1999).

8. By state, I mean here the sovereign political body organized under one government, not a subordinate unit in a federal system. 
ing. ${ }^{9}$ Thus, while it may be convenient to speak of a notable lack of regulation over private police as a regulatory lapse, ${ }^{10}$ the state here is also taking a stance toward private policing, through its failure to act.

The discussion that follows examines the shifting status of private policing: first, by examining the history of skepticism and criticism directed at them during the late-nineteenth and early-twentieth centuries, particularly in media attention and in congressional investigations; second, by recounting the partnership model that first gained a foothold in studies sponsored by the federal government in the 1970s and 1980s; and third, by questioning the meaning and intentions behind the idea of partnership advanced today.

None of the historical moments examined here can be characterized as wholly critical or entirely positive. Nor do the attitudes described here represent the unified efforts of one group or individual. If anything, each critical moment, viewed with the benefit of hindsight, represents but one choice over other possibilities. Indeed, the evolution of public attitudes toward private policing demonstrates that the emerging conventional wisdom of partnership was hardly an inevitabie resuit. We can extend this observation further: The history of private police entanglement in unsavory events suggests that the increased adoption of these partnerships will likewise see its own share of problems.

\section{The Emergence of Private Policing as a Threat}

From their emergence in the nineteenth century as competitors of the public police, to their targeting by congressional investigation in the early-twentieth century, private police have been the recipients of criticism and rebuke. Their very existence, as this section shows, raised fundamental doubts about the ability of the state to take care of its own citizens.

\section{A. Competing with the New Public Police}

The slow establishment of public police departments in American cities of the nineteenth century, ${ }^{11}$ and the even slower turn toward a professional, highly-

9. I have very loosely adapted this idea from Howard Becker's observations on the involvement of the state in art. See Howard S. Becker, Art Worlds 165-91 (1982).

10. Cf. Joh, supra note 4 , at $107-09$ (describing the paucity of current regulation on private police behavior).

11. See Eric H. Monkkonen, Police in Urban America, 1860-1920, at 42 (1981) (citing the gradual transition from a constable-watch system to the establishment of public police departments in Boston, 1838-59; in New York, 1843-53; and in Cincinnati, 1848-59). 
trained police force, ${ }^{12}$ led many people to rely upon the services of private detective agencies and watchmen services. ${ }^{13}$ The average public patrol officer of the late-nineteenth century was well-paid compared to other skilled urban workers, but poorly trained, if at all. ${ }^{14}$ Moreover, his ${ }^{15}$ relative isolation while working his "beat," compounded by the lack of technological means to communicate with the precinct station house, encouraged behavior that relied more on wits and practical experience than on formal law. ${ }^{16}$ Deficient, too, in the eyes of many urban dwellers were the small number of available public officers, made even less helpful by their poor organization. ${ }^{17}$

Urban residents in particular were already acquainted with an informal, private system for the retrieval of stolen property, operated by the constabulary,

12. See, e.g., Samuel Walker, A Critical History of Police Reform: The Emergence of Professionalism 56-57 (1977) (arguing that the signs of professionalism in policing, such as journals and organizations, did not completely emerge until the twentieth century).

13. There appears to be no reliable source for estimating the number of private police in the United States in the nineteenth century, save for the records of a few companies and the occasional newspaper report. Before a congressional investigative committee, Robert Pinkerton of the Pinkerton National Detective Agency said that his company employed 600 persons, but this number included guards, detectives, clerks, and stenographers. See H. R. Rep. No. 52-2447, at 193 (1893); see also Private Police Equals McAdoo Force in Numbers, N.Y. Times, Jan. 22, 1905, at SM4 (stating that there were in New York City "upward of 4,000 special policemen" as "guardians of private property," a number that was "equal in numbers to the force of policemen that [the Police] Commissioner McAdoo ha[d] on duty for the night patrols in both boroughs").

14. See David R. Johnson, Policing the Urban Underworld: The Impact of Crime on the Development of the American Police, 1800-1887, at 90-94, 101-03 (1979); see also Mark H. Haller, Historical Roots of Police Behavior: Chicago, 1890-1925, 10 LAw \& Soc'Y REv. 303 (1976) (arguing that public police in the nineteenth century were not particularly oriented toward legal norms).

15. Until the last half of the twentieth century, policing was an exclusively male occupation, with the exception of police matrons responsible for female prisoners. See Albert J. Reiss, Jr., Police Organization in the Tiventieth Century, 15 CRIME \& Just. 51, 61 (1992), reprinted in Modern PolicING, supra note 7, at 51,61 .

16. See Johnson, supra note 14, at 109-10; Samuel Walker, "Broken Windows" and Fractured History: The Use and Misuse of History in Recent Police Patrol Analysis, in Classics in Policing 97, 101 (Steven G. Brandl \& David E. Barlow eds., 1996) (observing that the adoption of the two-way radio and the patrol car increased response to citizen complaints).

17. See Johnson, supra note 14, at 119 . The new police also initially balked at the idea of wearing uniforms (though not at carrying firearms). See Roger Lane, Urban Police and Crime in Nineteenth-Century America, 15 Crime \& Just. 1, 11-12, 15 (1992), reprinted in Modern Policinc, supra note 7 , at $1,11-12$. 
for a fee. ${ }^{18}$ In the era before the "new" police were established, constables found little contradiction in simultaneously performing what we would think of today as private and public duties. Constables developed mutually agreeable relationships with a new class of "underworld" informers: the provision of information meant no arrest. ${ }^{19}$ When these constables became incorporated into the fledgling public police departments, many victims of property crime continued to offer discreet rewards to them for the return of stolen goods. ${ }^{20}$ After a number of wellpublicized scandals, however, state courts moved to prohibit the availability of a reward system to the public police. ${ }^{21}$

Yet the concept of private compensation for police work did not disappear. Many former constables responded to legal prohibitions on rewards by forming, in the 1840s, private organizations of "Independent Policemen" that targeted pickpockets and burglars..$^{22}$ By the 1860 s, for ten to twelve dollars a week, banks and other businesses could engage the services of private investigators to test their employees' honesty. ${ }^{23}$ These private services "siphoned off some of the best talent available to the new [public] departments and provided citizens with an alternative means of recovering property." 24 Private police also filled needs in the rural western United States, where in some areas virtually no public police existed at all..$^{25}$

18. See Johnson, supra note 14, at 45-47; Stephen Davies, The Private Provision of Police During the Eighteenth and Nineteenth Centuries, in The Voluntary City 151, 158 (David T. Beito et al. eds., 2002) (noting that advertisements seeking information on stolen property and for prosecution began to appear in British newspapers in the 1730s).

19. See Johnson, supra note 14 , at 47.

20. See id. at 48-50. Johnson describes in detail how the private reward system discouraged public officers from seeking arrests. Id. at $41-67$.

21. Id. at 50; see also Pool v. City of Boston, 59 Mass. (5 Cush.) 219 (1849) (holding that a city watchman could not recover an award for apprehending an arsonist); Hatch v. Mann, 15 Wend. 44, 49 (N.Y. 1835) (holding "[ $t$ ] hat a public officer, whose fees are prescribed by law, may maintain an action to recover an additional sum promised him by a party for doing his official duty, is a monstrous proposition, fraught with every kind of mischief"); Smith v. Whildin, 10 Pa. 39, 40 (1848) ("It would open a door to profligacy, chicanery, and corruption, if the officers appointed to carry out the criminal law were permitted to stipulate by private contract ....").

22. Johnson, supra note 14, at 60 (noting their establishment in St. Louis, 1846; in Baltimore, 1847; and in Philadelphia, 1848).

23. Private Detectives, Letter to the Editor, Private Detectives: A Defence of the System by One of the Craft, N.Y. Times, May 22, 1869, at 2.

24. JoHnson, supra note 14, at 60.

25. See Robert P. Weiss, An Interpretation of the Origin, Development and Transformation of Private Detective Agency Policing in the United States, 1850-1940, at 32 (Aug. 20, 1979) (unpublished Ph.D. dissertation, Southern Illinois University at Carbondale) (on file with author). 
Without the protection of a national police force, ${ }^{26}$ railroad companies like the Illinois Central, Michigan Central, Michigan Southern, and others--necessarily crossing multiple jurisdictional boundaries within their ordinary course of business-turned to private police firms. Of these, the most prominent was the detective agency founded by Allan Pinkerton in $1850 .{ }^{27}$

Although they did not want for business, these private police were not free from criticism. ${ }^{28}$ Some public officials complained of the perceived competition between private and public police, as did Chicago mayor John Wentworth (1857-58; 1860-61), for example, at his 1857 inaugural address. He stated:

Our police system has been gradually falling into disrepute; and it is a lamentable fact that, whilst our citizens are heavily taxed to support a large police force, a highly respectable private police is doing a lucrative business. Our citizens have ceased to look to the public police for protection, for the detection of culprits or the recovery of stolen property. ${ }^{29}$

26. While the Postal Inspection Service existed before the Declaration of Independence, the Federal Bureau of Investigation (initially the Department of Justice's Bureau of Investigation) was not created until 1924. See William A. Geller \& Norval Morris, Relations Between Federal and Local Police, 15 Crime \& Just. 231, 243 (1992), reprinted in Modern Policing, supra note 7, at 231, 241-42. Nor were there many state-wide police during the late-nineteenth and early-twentieth centuries. By 1900, only three states-Texas, Massachusetts, and Arizona-had established state police departments. Frank Morn, "The Eye That Never Sleeps": A History of the Pinkerton National Detective Agency 168 (1982).

27. See Milton Lipson, Private Security: A Retrospective, 498 Annals Am. Acad. Pol. \& Soc. Sci. 11,17 (1988) (describing the employment of Pinkertons by railroad companies). In the 1870 s and 1880 s, the railroad companies became increasingly reluctant to pay Pinkerton's rates and were wary of negative publicity regarding the private police. Morn, supra note 26, at 94 . Eventually, a number of states enacted legislation that allowed railroads to establish their own police forces with peace officer powers. By 1914, there were between 12,000 and 14,000 such railway police. NAT'L Advisory Comm. on Criminal Justice Standards and Goals, Private Security 31 (1976) /hereinafter Nat'l Advisory Comm. Report].

28. Of private store detectives, for instance, a New York Times editorial commented: "Instances of consummate ability on the part of detectives in the higher walks of their profession are sufficiently rare; among the astute persons who dog the steps of suspected visitors in front of shopcounters, hopeless stupidity seems to be disagreeably prevalent." Editorial, N.Y. Times, May 28, 1878 , at 4 .

29. John Wentworth, Mayor, City of Chicago, Ill., Inaugural Address (Mar. 10, 1857), in CHI. Daily Democrat, Mar. 11, 1857, available at http:/www.chipublib.org/004chicago/mayors/ speeches/wentworth57.html. 
Others more directly faulted the questionable methods employed by some private police officers. Newspaper accounts reported of "outrageous iniquities" perpetrated by private detectives in divorce cases, and of those who engaged in "sweating," or threatening, potential complainants from going to the public police about their clients. ${ }^{30}$ Courts took notice of the poor reputation of private detectives. By the end of the 1880 s, most states required the corroboration of a private detective's testimony before accepting it in matrimonial cases. ${ }^{31}$ The highest court of New York state, for instance, observed in 1889 that the testimony of "prostitutes and private detectives" was to be given little weight in divorce cases. ${ }^{32}$

\section{B. "Knights of Capitalism"33}

After the Civil War, coal-mining, manufacturing, and steel-production companies turned to private police agencies like Pinkerton's not simply for property protection, but also to combat labor-related violence. This was no small task. The federal Department of Labor estimated that between 1881 and 1900, some 22,793 strikes had occurred throughout the country. ${ }^{34}$ It was their role in quelling labor unrest that would bring private police their greatest disrepute until the time of the New Deal. ${ }^{35}$ Of the private police services, the Pinkerton National Detective Agency played a leading role in providing these companies with employees to act as strike guards, "scabs" (substitute workers), undercover agents, and "strike missionaries." ${ }^{36}$ In the period from 1866 to 1892 , the Pinker-

30. See, e.g., Entering Private Rooms by Force, N.Y. TIMEs, Nov. 16, 1880, at 8; The PrivateDetective Abuse, N.Y. Times, Jan. 25, 1889, at 5.

31. MoRn, supra note 26, at 76.

32. Moller v. Moller, 22 N.E. 169 (N.Y. 1889).

33. This term is borrowed from Morn, supra note 26, at 91.

34. U.S. Bureau of Labor, Strikes and Lockouts, Sixteenth Annual Report of the ComMISSIONER OF LABOR 340 (1901). While the Pinkerton agency provided guards to race tracks in the $1890 \mathrm{~s}$ and $1900 \mathrm{~s}$, in the $1880 \mathrm{~s}$, the guard system was used chiefly in strikes. MorN, supra note 26, at 99. See also S. Rep. No. 52-1280, at 63 (1893).

35. George Rigakos observes that similar police forces existed in Canada and Britain during this period, but did not engage in the same degree of violent activity. George S. Rigakos, The New Parapolice 11 (2002).

36. Strike missionaries either urged strikers to violence or acted as propagandists against the strike. See Strikebreaking Services, S. Rep. No. 76-6, pt. 1, at 2 (1939); Weiss, supra note 25, at 9899 (describing types of private police involvement); Campbell v. Commonwealth, $84 \mathrm{~Pa} .187$ (1877) (describing the infiltration of the "Molly Maguires," a group of Irish immigrant coal miners involved in labor violence, by James McPharlan, an undercover Pinkerton detective). 
ton agency alone took part in seventy strikes. ${ }^{37}$ By the end of the nineteenth century, "Pinkerton" had become a generic term for all private police. ${ }^{38}$

Although the private police in all forms drew some criticism from the press during the last two decades of the nineteenth century, ${ }^{39}$ the Homestead Riot of July 6, 1892_ "an epic in labor history" +0 - proved to be a decisive moment of public scrutiny. Facing a strike by workers in his Homestead, Pennsylvania steel works, Henry Clay Frick of Carnegie Steel arranged to have some 300 Pinkerton guards travel by rail to Youngstown, Ohio, where they embarked on barges down the Monongahela River to Homestead. ${ }^{41}$ Mistaking the guards for scabs, the striking workers engaged in exchanges of gunfire with the frightened Pinkerton guards (many of whom appear to have been misled about their assignment). ${ }^{42}$ Three workers and seven guards were killed, and scores more were wounded. ${ }^{43}$ Outnumbered, the Pinkerton guards surrendered, and were beaten by an angry mob. ${ }^{44}$ State troops called by the state's governor occupied the plant without incident four days later. ${ }^{45}$

37. Robert Pinkerton gave this number in his testimony to the Senate committee investigating the Homestead riots. S. ReP. No. 52-1280, at 247 (1893).

38. Morn, supra note 26, at 102.

39. A number of states, responding to public antipathy to "Pinkerton men," passed laws between 1879 and 1911 that, for the most part, either prohibited the importation of guards from other states or forbade employment of armed guards within the state under specified circumstances. S. REP. No. 76-6, pt. 1, at 14-17 (1939); see, e.g., Sorving Sharp Language, N.Y. Times, Jan. 22, 1887, at 3 (reporting adoption by the State Trades Assembly in Albany of a resolution criticizing "a section of the mobilized army of Hessian murderers, known as the Pinkerton detectives" and stating that "there should be a law forbidding the employment of armed or unarmed men of any private police force for any purpose whatever").

40. J. Bernard Hogg, Public Reaction to Pinkertonism and the Labor Question, 11 PA. Hist. 171, 179 n.23 (1944).

41. The story of the Homestead event is recounted in numerous sources. See, e.g., H.R. REP. No. 52-2447, at vi-ix (1893); William C. Oates, The Homestead Strike, 155 N. Am. Rev. 355 (1892).

42. See S. ReP. No. 52-1280, at 68-69 (testimony of John W. Holway).

43. Oates, supra note 41 , at 360.

44. H.R. Rep. No. 52-2447, at ix (1893).

45. See Lipson, supra note 27, at 19-20. Several of the strikers were later indicted for treason. See The Homestead Case, 1 Pa. D. 785 (1892). 


\section{Federal Investigations}

National attention to Homestead ${ }^{46}$ prompted investigations by Congress, although the House of Representatives had already begun to turn its attention to private policing before July of $1892 .{ }^{47}$ In support of a House resolution to examine private policing, Representative William Jennings Bryan (1891-95) had declared in May that the protection of life and property "should not be transferred to private individuals and hired detectives until we are ready to acknowledge government a failure. ${ }^{38}$ In November of 1892, a Senate committee, in hearings in Chicago, Pittsburgh, and New York, heard testimony not just from the Pinkerton agency but also from its competitors, including Thiel's Detective Service, the United States Detective Agency, Mooney and Boland Detective Agency, and the Illinois Detective Agency, about their role in policing labor unrest. ${ }^{+9}$

Both the House and Senate committees were highly critical of the use of private police against striking workers, but placed blame on the states for failing to provide public protection for the employers' unquestioned right to defend their private property. In its concluding statements, for example, the Senate investigative committee stated that the "use of private armed men is an assumption of the State's authority by private citizens." 50 "Anarchy" was inevitable where "the State is incapable of protecting its citizens in their rights of person and property ...." ${ }^{11}$ Likewise, the report of the House of Representatives both reaffirmed the right to protect private property and condemned the "sloth and dilatoriness of the civil authorities to render efficient and prompt protection to persons and property." 52

46. See, e.g., Editorial, N.Y. Times, July 7, 1892, at 4 ("There is no doubt that the employment by capitalists of a large force of trained private police in case of trouble with workmen has a very exasperating effect. A force of this kind causes fierce antipathy where regular officers of the law might command respect and submission.").

47. Representative Thomas Watson had suggested an investigation in January of 1892, 23 Conc. Rec. 4225 (1892), but an inquiry did not begin in earnest until after the Homestead riots.

48. Id. (statement of Rep. Bryan).

49. See generally S. Rep. No. 52-1280 (1892).

50. Id. at xv.

51. Id.

52. H.R. Rer. No. 52-2447, at xv-xvi (1893); see also id. at xxviii (views of Congressman James Buchanan) (" $[\mathrm{I}] \mathrm{t}$ is said that owners of property must be enabled to protect their property. So they must.... [But] [t]o attempt to supplant [the public] system by the introduction of irresponsible hirelings by each property owner, as he in his own mind determines they are needed, is to permit 


\section{The Forgotten Threat: Private Policing and the State 367}

Despite drawing national attention to their abuses, ${ }^{53}$ the Homestead hearings failed to produce meaningful changes in the regulation of private policing. ${ }^{54}$ The Homestead controversy did, however, midwife passage of the "Pinkerton law, ${ }^{55}$ prohibiting the federal government and the District of Columbia from hiring any "employee of the Pinkerton Detective Agency, or similar agency," as well as similar provisions in the states. ${ }^{56}$ Loopholes in these new laws, however, failed to prevent private police agencies from continuing to profit from laborrelated work. ${ }^{57}$ Criticism had failed to materialize into restraint.

(Of course, private police were not entirely free from legal scrutiny in this period. Pennsylvania courts appear to have been particularly wary of them, perhaps because the Homestead riot was so familiar. Some Pennsylvania state court judges, for example, denied applications for private detective licenses solely on the ground that there were too many in the profession already. $)^{58}$

each man to set up a government of his own at his own will."); The Homestead Case, 1 Pa. D. 785 , 789 (1892) (stating that Carnegie Steel "had the undoubted right to protect its property"). As J. Bernard Hogg notes, however, the condemnation of private policing did not translate into greater sympathy for striking workers. See Hogg, supra note 40, at 195 (noting that "all classes were agreed on the inviolate rights of property and the sanctity of the individual right of contract").

53. It was the conclusion of both the Senate and Congressional hearings that any regulation over private policing had to be left to the states, not the federal government. See, e.g., S. Rer. No. 52-1280, at xv; H.R. ReP. No. 52-2447, at xv.

54. See Morn, supra note 26, at 103 (noting that both investigations "were filled with antiPinkerton rhetoric, but [in the end] gave only conservative recommendations"); MiLton Lipson, On Guard: The Business of Private Security 163 (1975) ("In practice . . this archaic provision and its tortured interpretations have been no barrier to the use of employees of Pinkerton's or other similar organizations, both directly and indirectly by the United States government."). In fact, the 1895 Pennsylvania state law originally intended to allow coal companies to deputize their own police is being used today by homeowners' associations in the Pocono mountain area to establish their own private police forces. See Andrew Stark, Arresting Developments: When Police Power Goes Private, Am. Prospect, Jan.-Feb. 1999, at 41.

55. See Strikebreaking Services, S. Rep. No. 76-6, pt. 1, at 13 (1893).

56. Act of Mar. 3, 1893, ch. 208, 27 Stat. 572, 591. The Pinkerton law, in slightly modified form, remains good law. See 5 U.S.C. $\$ 3108$ (2000). See also MorN, supia note 26, at 107 (noting that by 1899, twenty-four states and the District of Columbia prohibited armed guards from entering their jurisdictions). Morn observes that the laws had little effect because the agencies could recruit private police within states. See id. at 107-08.

57. See Weiss, supra note 25, at 103.

58. See, e.g., Burnett's Application, 5 Pa. D. 3 (1896) ("The private detective has so much power for evil that I feel such appointments should only be made in cases of clear necessity."); Shelley's Petition, 1 Pa. D. \& C. 552, 553 (Dauphin Co. 1921) ("It is quite possible that if a license were granted to each and every applicant complying with the requirements of the act, to say the least, a 
After Homestead, Pinkerton's agency reduced its dependence upon strike work as a source of revenue, focusing instead on combating professional jewelry and banking theft, but newer agencies filled the needs of industry. ${ }^{59}$ Frank Morn, in his historical account of the Pinkerton agency, describes the first two decades of the twentieth century as a "golden age" of the private police. ${ }^{60}$ Their prosperity was not limited to strike work. The emergence of department stores that displayed goods on open shelves, for instance, brought with it increased rates of shoplifting. ${ }^{61}$ In response, store owners often banded together to establish protective groups, like the Mutual Protective Association of New York, founded in 1919, which provided private detectives to member stores and maintained a "rogues' gallery" of repeat offenders. ${ }^{62}$ Other individual stores had long employed their own police, such as Mary Plunkett, the "woman detective of New York City's Macy \& Co. ${ }^{33}$ Other private police agents stopped petty theft, patrolled rail yards, served warrants, protected small businesses, and even captured Army deserters for the federal government. ${ }^{\text {ft }}$

community might be so overrun with detectives that they may become meddlesome and vexatious."); cf. Farley's Petition, 8 Pa. D. \& C. 795, 796 (Phila. Co. 1927) ("The business of a private detective has long been recognized as of such a nature that, for the public protection, it should be restricted to persons whose characters are clean and above suspicion.").

59. See Morn, supra note 26, at 106, 167.

60. Id. at 169. In Philadelphia, for example, private detective agencies grew from 14 in 1900 to 37 in 1908, and in Chicago from 34 in 1910 to 58 in 1918. Id.

61. See Kerry Segrave, Shoplifting: A Social History 18 (2001).

62. Jail Terms Reduce Xmas Shoplifting, N.Y. TIMEs, Dec. 24, 1921, at 3 (describing activities of Association); Stores Open War on Amateur Pilferers, N.Y. TImes, July 11, 1920, at E1 (describing Association's clearing house); Shoplifters Plead Prices as Excuse, N.Y. Times, June 6, 1920, at 23 (describing arrest of 52 shoplifters by agents of Association); Shoplifting Has Both Its "Pros" and Amateur;, N.Y. Times, Aug. 3, 1924, at X9 (noting that Association's chief detective had been a detective sergeant in the New York Police Department for 16 years); The Shoplifting Profession, N.Y. Times, Mar. 23, 1930, at X17 ("In the 'Rogues Gallery' of store thieves-a collection of photographs furnished to all member organizations by the Stores' Mutual Protective Associationthere are pictures of 850 men and women who have at some time been convicted as shoplifters, pick pockets, impostors or bad check passers.").

63. Mrs. Martin's Dual Role, N.Y. Ti mes, Apr. 11, 1895, at 8; see also Pilfering from Stores, N.Y. Times, Mar. 4, 1883, at 5 (observing that "hired detectives are ever on the lookout for thieves..., but where one is caught a dozen will escape with their booty").

64. Glimpses of the variety of private police work appear in the case law of this period. See, e.g., Abbott v. Cooper, 23 P.2d 1027 (Cal. 1933) (residential patrol); Hallen v. Montgomery Ward \& Co., 281 N.W. 291 (Minn. 1938) (department store detective); Kobbe v. Chicago \& N.W. Ry. Co., 216 N.W. 543 (Minn. 1927) (rail yard patrol); Newport v. Montgomery Ward \& Co., 127 S.W.2d 687 (Mo. 1939) (store detective); In re Miller's Detective License, 17 Pa. D. 259 (Pa. Quar. Sess. 1908) (capturing deserters); McClain v. Lawrence County, 14 Pa. Super. 273 (1900) (serving warrants); Draughon v. Fox-Pelletier Corp., 126 S.W.2d 329 (Tenn. 1939) (residential patrol). 
By the 1930s, however, the continued involvement of private police in violent labor riots ${ }^{65}$ prompted yet another series of congressional investigations. ${ }^{66}$ On June 6, 1936, the Senate Committee on Education and Labor created a subcommittee chaired by Senator Robert La Follette, Jr. (1905-25) to investigate anew the role of private policing in strikes. ${ }^{67}$ Not only had little apparently changed since Homestead, the tactics of private police had become more violent. Private police agencies had replaced their Winchesters with chemical munitions and machine guns. ${ }^{68}$ Based upon testimony and records given by the five "most prominent" private agencies involved in strike work, ${ }^{69}$ the La Follette Committee determined that strikebreaking services "accounted for a substantial portion" of each firm's annual income. ${ }^{70}$

Documented in the thousands of pages of the La Follette Committee's reports, the use of private police to squelch labor organization was remarkable in scope. No employer facing a labor crisis, it seemed, went without the aid of private police assistance. Examples abounded. The West Point Manufacturing Company, concerned about a planned strike in 1934, arranged with the local sheriff to deputize more than one hundred men to police its textile mills dotted along the west bank of the Chattahoochee River. ${ }^{71}$ According to a resident of Lanett, Alabama, West Point's private police blocked the only paved highway in the area and "stoplped] and search[ed] every car there."72 In 1936 and 1937,

65. See Shot in Strike Battle, L.A. TIMEs, Mar. 23, 1913, at VI7 (describing violence between strikers and private police in West Morrisville, N.J.); 3 Killed, 19 Shot, Town Set Afire, Ohio Militia Out, N.Y. Times, Jan. 8, 1916, at 1 (describing riot at Youngstown, Ohio); Rioting in Youngstown, Troops on the Way, L.A. Times, Jan. 8, 1916, at I1.

66. Nor had the press or Congress been silent in the interim. See, e.g., Strike Inquiry Demanded from Floor of House, Christian Sci. Monitor, Feb. 9, 1928, at 2 (noting the demands of Representative Fiorello LaGuardia and John Casey for investigation into labor conditions and of the private police of coal operators).

67. See Strikebreaking Services, S. Rep. No. 76-6, pt. 1, at 201 (1939). For an in-depth discussion of the La Follette Committee's role in shaping views on civil liberties and workers' rights, see Jerold S. Auerbach, Labor and Liberty: The La Follette Committee and the New Deal (1966).

68. See Industrial Munitions, S. Rep. No. 76-6, pt. 3, at 184-90 (1939).

69. These were Pinkerton's National Detective Agency, Inc.; Railway Audit \& Inspection Co., Inc.; Corporations Auxiliary Co., Inc.; Wm. J. Burns International Detective Agency, Inc.; and National Corporation Service, Inc. S. Rep. No. 76-6, pt. 1, at 19 (1939).

70. See id. at 20.

71. See id. at $42-44$.

72. See id. at 45 . 
members of the 350-person police force of the Republic Steel Corporation ${ }^{73}$ used "rough shadowing" (constant open surveillance sometimes rising to physical intimidation) against union leaders, organizers, and members in Youngstown and in Canton, Ohio. ${ }^{7 \uparrow}$ The Glenn E. Bodell Industrial Detectives company was one of many private police agencies that received a "flourishing business" in providing undercover agents and guards to employers in the Salinas, California, lettuce-packers' strike of $1936 .{ }^{75}$ In Los Angeles, restaurant owners "followed the reprehensible practice of hiring municipal policemen for strike duty" in a 1937 strike against the Brown Derby restaurant. ${ }^{76}$

The Committee's conclusions were sweeping and condemnatory. The sole purpose of these "private police system[s],"77 it concluded, was to "defend the interests of the employer, whether an individual or corporation"; any "exercise [of] the nonpartisan functions of guardian of the law" was "incidental." 78 The only legitimate role that a privately funded police agency could assume was the "protection of life and property." 79 Whenever private police exceeded these activities they "act[ed] only as an instrumentality of private economic policy." ${ }^{80}$ The La Follette Committee drew a sharp contrast between the responsibilities and status of public and private police:

Public police systems are established by law. They are paid from public treasuries and are expected to be responsive to the requirements of entire communities. They must perform their duties impartially, without regard to the economic, racial, or religious status or views of the individual members of the community. The final

73. See Private Police Systems, S. Rep. No. 76-6, pt. 2, at 116 (1939).

74. The "Little Steel" Strike and Citizens' Committees, S. Rep. No. 77-151, pt. 4, at 96-97 (1941).

75. See Employers' Associations and Collective Bargaining in California, S. Rep. No. 78398, pt. 3, at 1377 (1943).

76. See S. Rep. No. 78-398, pt. 2, at 841 (1943).

77. The Committee used the term "private police" in a specific sense: the creation by corporations of their own private guard and espionage departments "to achieve the same results obtainable through the employment of industrial detective and strikebreaking agencies." See S. Rer. No. 76-6, pt. 3, at 1 (1939). The Committee's views on these private police, however, are consistent with their views on private policing work offered by the detective agencies and employers associations they also studied.

78. See S. Rep. No. 76-6, pt. 2, at 2 (1939).

79. Id.

80. Id. 


\section{The Forgotten Threat: Private Policing and the State 371}

responsibility for the actions of public police systems rests in elected representatives who are accountable to the electorate....

Private police systems, on the other hand, are created to meet the economic needs and desires of private interests. They are paid from private funds and act as the agents and servitors of their employers, who occupy their positions by virtue of their ownership of property or as appointed agents of stockholders or owners.... Private police systems, therefore, cannot be viewed as agencies of law and order. ${ }^{81}$

As with the Homestead investigations, the reports of La Follette's committee resulted less in regulatory change than it did in reinforcing an unfavorable image of private policing. As one consequence, the Pinkerton Agency formally withdrew from all labor-related policing work in $1937 .{ }^{82}$

Contemporary criticism of private police agencies was not limited to their involvement in labor strikes. Even the U.S. Supreme Court, in a 1937 criminal case that depended largely on the testimony of private railroad police, took note of their poor social standing: "Common experience teaches us that the testimony of such witnesses, especially when uncorroborated, is open to the suspicion of bias....."83

In their totality, the editorials, congressional testimony, public reports, and newspaper articles from the post-Civil War period until the second World War reveal an attitude of skepticism and antagonism toward private policing. While the congressional investigation of 1939 , like its predecessor, focuses only on the role of private policing in labor unrest, each demonstrates deeply ambivalent attitudes regarding the proper role of privately paid police forces. No report or ed-

81. Id.

82. See Morn, supra note 26, at 188 (describing April 1937 general order number 105 of Pinkerton Agency ordering withdrawal).

83. District of Columbia v. Clawans, 300 U.S. 617, 630-31 (1937); see also People v. Loris, 115 N.Y.S. 236, 239 (N.Y. App. Div. 1909) (“And although Mr. Sawyer was neither an accomplice, nor an odious witness, whose testimony was to be discredited, yet, in view of his employment as a detective, his testimony was to be received 'with the greatest care and distrust,' [as was] said of a witness in a like case.") (citation omitted); Gassenheimer v. United States, 26 App. D.C. 432, 446 (D.C. Cir. 1906) ("Where one or more of the facts essential to conviction depend upon the evidence of detectives especially employed to procure evidence of the crime, it is eminently proper for the court to call attention [of the jury] in some way to the possible bias or prejudice of such witnesses, as compared with those who are apparently impartial and disinterested." (bracketed text in original)). 
itorial questioned the right to defend one's property or person, ${ }^{84}$ and yet there existed "the grave problem of the responsible functions of public officials being usurped by the agents of private corporations." ${ }^{85}$ The precise boundary between self-defense and illegitimate force was not specified. Moreover, some observers, including public police chiefs, conceded that private police were a necessary evil to be tolerated because public officers could not be everywhere. ${ }^{86}$

84. See, e.g., 23 Conc. Rec. 4225 (1892) (statement of Rep. Bryan) ("It is not fair to compel corporations to protect their property in this way, nor is it right that the safety and even life of the citizen shall be imperiled by a private and irresponsible soldiery."); The Homestead Case, 1 Pa. D. 785, 789 (1892) ("The company had the undoubted right to protect its property ...."). In a 1955 case involving a private police agency employed by the town of Kalamazoo, Michigan, the dissenting judge, while denouncing the use of private police for public uses, stated:

The corporate deputy is no stranger to the law. His face has often appeared in the courts. See Hearings before a Sub-committee of the Committee on Education and Labor, United States Senate, pursuant to Senate Resolution 266, 74th Congress, $2 \mathrm{~d}$ Sess. (1936-1939). If he has any place in our scheme of government it is behind the company fence, not on the public highways.

People v. Robinson, 74 N.W.2d 41, 47 (Mich. 1955) (Smith, J., dissenting). But see State v. Kerner, 107 S.E. 222, 225 (N.C. 1921) ("[T] [Tere are still localities, not necessary to mention, where great corporations, under the guise of detective agents or private police, terrorize their employees by armed force. If the people are forbidden to carry the only arms within their means, among them pistols, they will be completely at the mercy of these great plutocratic organizations.").

85. Private Police Systems, S. Rep. No. 76-6, pt. 2, at 215 (1939). The usurpation of public authority had been raised as an issue before. Representative Owen Scott (1891-1893), for example, in debating the 1892 resolution of the House to investigate private policing, argued:

It is commonly known in all parts of this country that the Pinkerton Detective Agency has assumed the functions of a private army. In all States and at all times it assumes to do that which is peculiarly the power of Government or of the State.... The liberties of large classes of people are threatened when individuals and corporations, without any sanction of law, are permitted to take and hold in custody without warrant of law such as they may choose to arrest.

23 Conc. Rec. 4224 (1892).

86. For instance, the 1939 Senate committee asked of Robert McClaughry, the chief of police for Chicago, his opinion of private police to protect property:

Q. And so far as these men are concerned you would rather favor their employment? - A. Yes, sir. It is impossible to provide a police force large enough to meet all the wants of business, and it is well enough to have an agency, reliable, to seek out and furnish, for business men, only reliable watchers.

S. ReP. No. 52-1280, at xi (1893). 


\section{The Apparent Retreat of Private Policing}

By the time of the Second World War, private police had not disappeared, but they received little of the public hostility they had experienced before. ${ }^{87}$ Those private agencies that had once provided coal and steel companies with private police now did so for defense contractors concerned both with petty theft and international, rather than domestic, espionage ${ }^{88}$ Companies that entered into defense contracts with the Department of Defense, like Pratt and Whitney Aircraft and the Aluminum Company of America (ALCOA) ${ }^{89}$ were required to establish security plans that the Federal Bureau of Investigation helped to create. ${ }^{90}$ At its Cleveland, Ohio steel works, the Jones and Laughlin Corporation employed in 1943 seventy-two "plant protection employees" deputized by the city of Cleveland. ${ }^{91}$ In deciding a labor dispute involving Jones and Laughlin and its private police force, the Supreme Court observed that "[i]t is a common practice in this country for private watchmen or guards to be vested with the powers of policemen, sheriffs or peace officers to protect the private property of their private employers." ${ }^{\prime 2}$ Not all private police were stationed at industrial plants. Small agencies continued to provide guards to businesses, and private detectives dredged up incriminating evidence for spurned spouses. ${ }^{93}$ After the war, some returning sol-

87. Shearing describes the 1950 s as a time when private policing "was considered an anachronistic institution," Shearing, supra note 7, at 408, reprinted in Modern Policinc, supra note 7, at 408 , but considering the continued employment of private policing by defense contractors and other employers this observation is overstated.

88. See, e.g., A.H. Raskin, G.M. Doubles Force to Curb Sabotage, N.Y. TImes, Apr. 5, 1942, at 35 ("To guard against spies and saboteurs in plants charged with responsibility for 10 per cent of the national arms program, the General Motors Corporation has doubled its private police force in the period since the Japanese assault on Pearl Harbor."); George R. Wackenhut, Business Espionage, Indus. SEcurity, Feb. 1966, at 4-8 (describing instances of industrial espionage and proposing countermeasures). Wackenhut was the founder of The Wackenhut Corporation, a national private police agency. See id. at 4 .

89. These companies were also members of the board of directors for the American Society for Industrial Security, the most prominent private policing professional organization, then and now. See, e.g., Indus. Security, Feb. 1958, at 3.

90. See Nat'l Advisory Comm. Report, supra note 27, at 31 .

91. NLRB v. Jones \& Laughlin Steel Corp., 331 U.S. 416, 419-21 (1947).

92. Id. at 429.

93. See, e.g., Schauder v. Weiss, 88 N.Y.S.2d 317 (N.Y. Sup. Ct. 1949) (alleging a conspiracy between a detective agency and the plaintiffs husband to procure divorce from the plaintiff); Agency for Investigation \& Detection, Inc. v. Dep't of State of N.Y., 262 N.Y.S.2d 694 (N.Y. Sup. Ct. 1965) (describing a break-in by private detectives to obtain evidence in a divorce case). 
diers even made use of the Servicemen's Readjustment Act to finance and to "establish police services outside the realm of public police forces." ${ }^{14}$ No further controversies on the scale of Homestead, however, surfaced.

(One notable exception was the employment in 1967 of the Wackenhut Corporation by then-Florida Governor Claude R. Kirk, Jr., to "drive organized crime out of [Florida]." 95 During its four month existence, Wackenhut's group arrested twenty-three people and opened five hundred investigations. While the Republican Kirk counted among the group's successes the elimination of a $\$ 780,000$-a-year narcotics operation, ${ }^{96}$ one report suggested that the majority of those investigated by the Wackenhut police were Democratic state officials. ${ }^{97}$ After vocal opposition by the Florida public police and several state legislators, Kirk abolished his private police force, and requested instead $\$ 1.5$ million from the state legislature to establish a special state police force. ${ }^{98}$ )

In the meantime, public policing had been undergoing its own changes. Beginning in the Progressive era, reformers ${ }^{99}$ introduced into these quasi-military bureaucracies ${ }^{100}$ legalistic and professional norms. ${ }^{101}$ Many police chiefs gained tenure and thereby acquired greater freedom from the influence of local politics. ${ }^{102}$ Newly established police academies offered formal training to recruits. ${ }^{103}$ No less important was the introduction of technological advances-the patrol car, the two-way radio, and the telephone (and later the computer)-that trans-

94. Vets Launch Security Services, Police Chiefs News, June 1947, at 24.

95. Martin Waldron, Florida's Governor Sets Up Private Police Force, N.Y. TImEs, Jan. 8, 1967, at 56; Martin Waldron, Private Police Scored, N.Y. Times, Jan. 9, 1967, at 28.

96. Kirk Says Private Police Broke Up Narcotics Ring, N.Y. Times, Mar. 15, 1967, at 32.

97. Martin Waldron, Florida Aroused by "War" on Crime, N.Y. TIMEs, Apr. 7, 1967, at 22.

98. Martin Waldron, Gov. Kirk Agrees to Give Up His Private Police, N.Y. Times, May 6, 1967, at 1. For a discussion of the legality of private police employment by a state governor, see generally Tamar Frankel, The Governor's Private Eyes, 49 B.U. L. Rev. 627 (1969).

99. Individuals like August Vollmer and his disciple, O.W. Wilson, were especially influential. See Gene E. Carte \& Elaine H. Carte, Police Reform in the United States: The Era of August Vollmer, 1905-1932, at 2-3 (1975); Samuel Walker, A Critical History of Police ReFORM 141-45, 161-63 (1977).

100. Reiss refers to nineteenth-century police organizations as "quasi-militaristic," by which he means "rationalized hierarchical authority [produced] by adopting the basic military form of hierarchical organization." Reiss, supra note 15, at 89, reprinted in Modern Policing, supra note 7, at 89.

101. For representative accounts of these reforms, see, e.g., Robert M. Focelson, Big-City PoLICE 93-116 (1977); W ALKER, supra note 99, at 109-37.

102. See Reiss, supra note 15, at 57, reprinted in Modern Policing, supra note 7, at 57.

103. WALKER, supra note 12 , at $161-64$. 
formed patrol work by allowing quick responses to citizen complaints by means of a centralized dispatch. ${ }^{10 t}$ A new sociology of the police emerged as well, but it omitted study of the private police. ${ }^{105}$

\section{Private Police as Partners}

\section{A. Federal Studies of Private Policing}

If at mid-century the private police appeared to be experiencing a modest decline (both in demand and employment), then new research in the 1970s raised questions about the accuracy of that view and the likely future for private police. Beginning in the 1970s, the Department of Justice sponsored a series of reports on private policing ${ }^{106}$ that were noteworthy in two respects. As an empirical matter, it turned out that private policing had not only continued to prosper in the second half of the twentieth century, but was now outpacing the public police in employment and expenditure. Perhaps more importantly, these reports first encourage and then display a change in attitude by public police chiefs, lawmakers, and other public officials about private policing, and provide a vocabulary to describe that shift. Rather than pose a threat to public police, private police, according to these reports, could serve as the public sector's new partner.

The reports first show in plain numbers how private policing had grown, unnoticed, at a dramatic rate in the 1960 s and 1970 s. ${ }^{107}$ The Hallcrest Report of

\section{Id. at 136-37.}

105. See Maureen Cain, Trends in the Sociology of Police Work, INT'L J. Soc. L., May 1979, at 143, 144-45. "Nobody questioned what 'the police' meant. Thus private police forces, citizen protection groups, and other government policing bodies, were ignored." Id. at 145.

106. The principal reports include: James S. Kakalik \& Sorrel Wildhorn, Private Police in the United States: Findings and Recommendations (1971); James S. Kakalik \& Sorrel Wildhorn, The Private Police Industry: Its Nature and Extent (1971); James S. Kakalik \& Sorrel Wildhorn, Current Regulation of Private Police: Regulatory Agency Experience and Views (1971); James S. Kakalik \& Sorrel Wildhorn, The Law and Private Police (1971); James S. Kakalik \& Sorrel Wildhorn, Special-Purpose Public Police (1971) [the foregoing five reports are a series hereinafter collectively referred to as the RAND REPORT in the text, but referred to individually in the footnotes]; Nat'l Advisory Comm. Report, supra note 27; William C. Cunningham \& Todd H. Taylor, Crime and Protection in America: A Study of Private Security and Law Enforcement Resources and Relationships (Daniel Ford ed., 1985); William C. Cunningham, John J. Strauchs \& Clifford W. Van Meter, Private Security Trends, 1970-2000: The Hallcrest Report II (1990) [hereinafter Hallcrest Report].

107. See generally Joh, supra note 4, at 67-71 (from which portions of this discussion are drawn). 
1990, commissioned by the Department of Justice, records not only this development, but also predicts that private police employment would continue to outpace that of public police well into the future, contradicting the predictions of a 1971 study issued by the Rand Corporation. ${ }^{108}$ According to the authors of the Hallcrest Report, private police employees would outnumber public police by a ratio of $2.8: 1$ by the year $2000 .{ }^{109}$

While the Rand Report was wrong on the pace of private police growth, it was probably the first major national study of several to suggest that private police could serve as a resource for public policing. ${ }^{110}$ The Report assumes explicitly that private police, who perform a variety of legitimate security roles, "fill a perceived need and provide clear social benefits to their consumers and to the general public."111 It also seeks to upend the conventional wisdom that policing is necessarily a government function. ${ }^{112}$ Policing, according to the Report's authors, is a "service" that can be assumed either by public or private agencies. ${ }^{113}$ While private police - some 289,000 guards and investigators in 1969-are primarily "concerned with private interests," including the "prevention and detection of crime on private property and the gathering of information for private purposes," the Rand Report nevertheless contends that most private policing is

108. The comparison concerns only private guards, but the difference between the two estimates is nevertheless noteworthy. Compare Hallcrest Report, supra note 106, at 229, with X RAND REPORT, supra note 106, at 17 ("By 1975, BLS projections indicate that there will be fewer combined private security workers and public guards than there will be public police”). By "public guard," the report refers to guards employed in the public sector without "peace officer" status. RAND REPORT, supra note 106, at 17.

109. See Hallcrest Report, supra note 106, at 229. According to the Report-which remains the most recent reliable source of figures - as of 1990, there were about 520,000 contract guards, 528,000 proprietary security personnel (personnel employed directly by a client of private policing services), 70,000 private investigators, and 2,900 "security engineers" ("employees deriving their primary income from [securityl consultation fees"). Id. at 185-88.

110. Shearing, supra note 7, at 409, reprinted in Modern Policinc, supra note 7, at 409 ("In retrospect, RAND's report can be identified as one of the earliest indications of the shift in political consciousness that has promoted the privatization of a whole range of services previously seen as fundamentally public." (citations omitted)).

111. Kakalik \& Wildhorn, Private Police in the United States, supra note 106, at 24; see also Inst. for Local Self Gov't, Private Security and the Public Interest 101 (1974) (accepting the "assumption" that "private security provides social benefits to the general community as well as to the users of security services").

112. This challenged conventional research on the police that drew from Max Weber's definition of the state as having a monopoly over the legitimate use of force. MAX Weber, Politics as a Vocarion 2 (H.H. Gerth \& C. Wright Mills trans., Fortress Press 1965) (1919); Joh, supra note 4, at 69.

113. Kakalik \& Wildhorn, Private Police in the United States, supra note 106, at 17. 
"complementary" to public policing. ${ }^{114}$ The problems within private policing identified in the Report-such as the unnecessary use of force and dishonest business practices-are not fundamental faults inherent to private policing, but technical issues amenable to improved regulation. ${ }^{15}$

Private police, in the view supported by the Rand Report, could serve as supplements, or "junior partners," to the public police, a shift in perspective accomplished by "blurring the line between 'self-defense' and peacekeeping." 116 Thus, individual examples of private protection, in the aggregate, contribute to general public safety. Similarly, a 1974 study, conducted by the Institute for Local Self Government (ILSF) and sponsored by California's Council of Criminal Justice, states that the private police

perform work that the regular police cannot or will not perform. The public police typically cannot be spared to prevent or to investigate certain suspected but unauthenticated crimes such as employee pilferage and, by law, they must refrain from crime prevention activities on private property unless asked to do so by the owner in specific instances. ${ }^{117}$

In this view, private police do not usurp public authority, but provide muchneeded aid to the public police.

Later studies took the additional step of suggesting that private police ought to be considered equal partners with the public police, rather than subordinates supplying a complementary service. The 1990 Hallcrest Report, for instance, identifies the "coproduction of security" as a goal to be met together by "public

114. Id. at 11, 16, 18. A 1974 study of private policing in California also describes the roles of public and private as "complementary [rather than] competitive." INST. FOR LOCAL SELF Gov'T, supra note 111, at 86; see also NAt' Advisory Comm. Report, supra note 27, at 19 (stating that "li|deally, public law enforcement and private security agencies should work closely together, because their respective roles are complementary in the effort to control crime. Indeed, the magnitude of the Nation's crime problem should preclude any form of competition between the two.").

115. Kakalik \& Wildhorn, Private Police in the United States, supta note 106, at viii-ix.

116. Shearing, supra note 7, at 411, reprinted in Modern Policing, supra note 7, at 411. Commentators have been similarly concerned about the blurring of defensive and offensive work performed by private military contractors in U.S.-occupied Iraq. See also David Barstow, Security Companies: Shadow Soldiers in lraq, N.Y. Times, Apr. 19, 2004, at Al (noting that, according to security company executives, the line between permitted defensive work and prohibited combative work is becoming "blurred").

117. See Inst. For Local Self Gov't, supra note 111 , at 88. 
law enforcement, private security, and citizens." 118 What was clear by 1990 that private police outnumbered public police-was not an occasion for alarm, according to the Report's authors, but an opportunity for the "realignment of roles and greater cooperation between the public and private sectors." ${ }^{119}$ Consequently, the "traditional approach" of public police "working independently of citizens and businesses / would have to] change." ${ }^{20}$ Public police would not only have to work more with these groups, but also reinvent themselves as "brokers" of security resources. ${ }^{121}$ Through these redefinitions, these reports challenged the premise that "policing" was primarily a government service. ${ }^{122}$

\section{B. Changing Public Police Attitudes}

The vocabulary of partnership also found support in the public police community, but not without initial resistance. The California Institute for Local Self Government, for example, found in its 1974 survey of 158 public police and sheriffs departments considerable reluctance about creating formal partnerships with private police agencies, chiefly because of concerns about the quality of private police employees. ${ }^{123}$ Similarly, a 1971 national survey reported that 40 percent of public police described their relationship with private security as only "fair" and 5 percent as "poor." 124

118. Hallcrest Report, supra note 106, at 312.

119. Id. at 319 .

120. Id. While the Report makes reference both to for-profit policing and to volunteer policing here, most of the Report focuses on private policing as it is defined here.

121. Id. at 320 .

122. See Private Security Advisory Council, Law Enforcement and Private Security Sources and Areas of Conflict and Strategies for Conflict Resolution 23 (1977) ("Private security and law enforcement, through a combined effort, must develop ways to enhance the delivery of services to clients and to the public.").

123. Inst. for Local Self Gov't, supta note 111, at 10,98; Nat'l Advisory Comm. Report, supia note 27 , at 20 (citing qualification of private security personnel as a "substantive barrier to effective interaction"); Private Security Advisory Council, supra note 122, at 2 (reporting that 55\% of public police surveyed viewed private police as "incompetent").

124. See Richard Post, Relations with Private Police Services, Police Chief, Mar. 1971, at 54-56; Thomas M. Scott \& Marlys McPherson, The Development of the Private Sector of the Criminal Justice System, 6 Law \& Soc'y Rev. 267, 282 (1971) ("Most law enforcement officers interviewed [in a Minnesota study] indicated that their attitudes toward the private police system are more positive at best, to ambivalent at least, while no one interviewed indicated that he had favorable attitudes toward and cooperative relationships with all private agents."). 
Advocates of partnership, like the Private Security Advisory Council established by the Department of Justice in 1977, attributed suspicion of the public police toward private police to "role conflict." 25 In the Council's view, the blame for role conflict rested squarely with the public police, who were preoccupied with perceived threats to their status, and who failed to see that private and public police were "both directed toward protective functions in society." 126

Public police chiefs disposed toward partnerships took two approaches to overcome these suspicions. Some, like Michael Shanahan, a "private sector liaison" for the International Association of Chiefs of Police, and police chief of the University of Washington, suggested that public police should not fight the inevitable dominance of private policing in controlling crime: "The preferences of public law enforcement officials are no longer a controlling factor in these developments." 127 Others emphasized the positive effects of enhancing public police power through public-private alliances, by tapping formerly unavailable resources (increased patrols), and by public police incorporation of private sector skills ("management by objectives"). ${ }^{128}$ According to one Los Angeles Police Department sergeant, "It's not that [the public police are] lazy, there aren't enough of us to go around." ${ }^{129}$ Similarly, in the view of Major Paul Fitzgerald, of the Providence, Rhode Island Police, partnerships present a "win-win situation for all of us." ${ }^{130}$ Through a reinterpretation of their role and capabilities, many of the threats once associated with the private police had been neutralized.

\section{The Advocacy of Partnerships}

By the end of the 1990s, the agenda for public police reform included publicprivate partnerships. Policymakers actively encouraged their creation. A 2000 re-

125. Private Security Advisory Council, supra note 122, at 4.

126. See id. at 4-6; Jack R. Greene et al., Merging Public and Private Security for Collective Benefit: Philadelphia's Center City District, Am. J. of Police, Issue 2 1995, at 3, 5 (attributing conflict to misunderstanding and competition between the two).

127. Michael G. Shanahan, Private Enterprise and the Public Police: The Professionalizing Effects of a New Partnership, in Police Leadership in America: Crisis and Opportunity 449, 449 (William A. Geller ed., 1985); Ralph Blumenthal, Private Guards Cooperate in Public Policing, N.Y. Times, July 13, 1993, at B1 (reporting that public police say that "there seems little choice but to join forces" with private police).

128. See, e.g., Shanahan, supra note 127, at 455 ("On the other side, law enforcement officials will be exposed to a higher degree of organizational sophistication.").

129. Nina Munk, Rent-a-Cops, Forbes, Oct. 10, 1994, at 104, 106.

130. Richard C. Dujardin, City Police Team up with Private Security Personnel, Providence J.Bull., Dec. 9, 2003, at C-01. 
port published by the Department of Justice, "Operation Cooperation," counts sixty cooperative programs throughout the country, and suggests that "[n]o city or metropolitan area should be without at least one."131 These programs vary in size and objectives, ranging from the thirty members of the Northeast Florida Law Enforcement and Private Security Council that share information on retail theft, to the one thousand-member New York Area Police/Private Security Liaison that established a business crime squad in midtown Manhattan. ${ }^{132}$ The private members of these alliances vary as well. Some are contract security companies and corporate police departments; others are private corporations themselves (that contract with private police agencies or employ their own). ${ }^{133}$ Whatever their identity, private members all share the same goals of promoting partnership with public police departments. ${ }^{134}$ Some examples are discussed below.

\section{Joint Investigations}

For some public police departments, the increased acceptability of partnerships has led to their greater willingness to enter into joint investigations with private police, both by lending public personnel, as well as by providing administrative and technical resources. Gary Marx discusses one such example: a sting conducted by the FBI and IBM that targeted the theft of technological trade secrets. ${ }^{135}$

The investigation began when a former employee informed IBM that he had been approached by the Hitachi Corporation about obtaining confidential computer information. ${ }^{136}$ After meeting with IBM security officers, the em-

13I. Inst. for law and Justice \& Hallcrest Div. of Sci. Applications Int'l Corp., Dep't of Justice, Operation Cooperation: Guidelines for Partnerships Between Law Enforcement and Private Security Organizations 1,3 (2000) [hereinafter Operation Cooperation].

132. Id. at 7-8; Anthony M. Voelker, NYPD's APPL Program: A New Partnership, FBI L. ENforcement Bull., Feb. 1991, at 1, 2; see generally S. Woodruff Bentley, An Alliance is Born, SecuRity Mcmt., Oct. 1997, at 77 (describing Virginia Police and Private Security Alliance). For a review of similar partnerships in Canada, see Rigakos, supra note 35, at 42.

133. See generally David R. Green, Joining Forces Against Crime, Security Mamt., May 1998, at 95 (describing The Business/Law Enforcement Alliance in California, which was established in 1994 and consists of private corporations and city, county, state, and federal law enforcement agencies).

134. Thus, the Operation Cooperation report lists among its examples both kinds of partnerships referred to here. Inst. for Law and Justice \& Hallcrest Div. of Sci. Applications Int'l Corp., supra note 131 , at 2-4.

135. Gary T. Marx, The Interweaving of Public and Private Police in Undercover Work, in Private Policing 172, 173 (Clifford D. Shearing \& Philip C. Stenning eds., 1987).

136. Much of this account is taken from Gary T. Marx. Id. at 173-74. 
ployee introduced Hitachi officials to members of "Glenmar Associates," a fictitious consulting firm created by IBM and the FBI (which had been informed later of the proposed corporate espionage) that offered to sell IBM secrets to $\mathrm{Hi}$ tachi. As a result of their joint undercover work, criminal charges were eventually filed against twenty-one people in 1982, including senior officials at Hitachi and at the Mitsubishi Electric Corporation. The defendants were accused of, among other things, paying $\$ 648,000$ to an undercover FBI agent in exchange for the stolen information. William $\mathrm{H}$. Webster, then-director of the FBI, praised IBM "for the excellent assistance rendered during this investigation." 137

\section{Information-Sharing Networks}

Many partnerships also provide a formal means to share information on crime patterns and suspects. While we know little about the history of these relationships, former public police officials in the private sector probably have long relied on their public police contacts for information. ${ }^{138}$ What is different about contemporary partnerships is their formal, public nature; these partnerships exist with the imprimatur of the public police department's official face, and by extension, the approval of a city, a state, or the federal government.

These groups typically have three purposes. First, they share from their respective departments information on crime patterns, suspects, ${ }^{139}$ and identification of "criminogenic"140 situations such as demonstrations. ${ }^{141}$ Second, many

137. Jeff Gerth, Japanese Executives Charged in I.B.M. Theft Case, N.Y. TImEs, June 23, 1982, at A1, D6.

138. See, e.g., Morn, supra note 26, at 170 (noting that ex-Secret Service agents formed their own detective agencies after retirement in the nineteenth century).

139. The practice of some private police departments to keep their own suspect files dates back to the Pinkerton agency's maintenance of a "|r|ogues galler[y]." Id. at 122.

140. "Criminogenic" situations are crime-causing ones. See generally Lawrence W. Sherman et al., Preventing Crime: What Works, What Doesn't, What's Promising 2-3 (1997), available at http://www.ncjrs.org/works/. Cf. David Garland, 'Governmentality' and the Problem of Crime: Foucault, Criminology, Sociology, 1 Theoretical Criminology 173, 187 (1997) (explaining that criminogenic situations, "hot spots of crime," present a new problem in controlling crime).

141. See, e.g., Dujardin, supra note 130, at C-01 (reporting Providence police chief as saying that "the most powerful element in [its] new partnership ... is the sharing of information between private and public agencies"); Christopher Lee, Police Aik Security Guards for Aid in Crime Crackdozm, Dallas Morning News, Mar. 6, 1997, at 25A (quoting Dallas police chief as describing its public-private partnership as "really about information exchange"); Voelker, supra note 132, at 2 (describing these activities with respect to the APPL partnership); Terence J. Mangan \& Michael 
partnerships, such as the Business/Law Enforcement Alliance of California, target particular categories of crime such as check fraud that concern their private members and ask the public police members of the partnership for assistance. ${ }^{1+2}$ Finally, regular meetings and personal contacts among private police executives and public police representatives circulate tokens of a common policing culture: "informal networks, similar tasks, and the exchange of personnel." +43

In one example, the shipping company FedEx recently convinced legislators in Tennessee, where it is headquartered, to amend state law so that FedEx could employ its own, ten-person sworn police force. ${ }^{1+1}$ This means that FedEx police may now "investigate all types of crimes, request search warrants and make arrests anywhere in the state." ${ }^{145}$ Although FedEx had long employed its own private police force, ${ }^{146}$ the state's conferral of peace officer status on the FedEx police department allows the company to occupy a seat on a regional task force run by the FBI. ${ }^{147}$ Membership on the task force permits FedEx to receive "more sensitive and specific information regarding terrorist threats than businesses usually receive." I+8

Some partnerships also operate in virtual space. After the terrorist attacks of September 11, 2001, the perceived vulnerability of the nation's telephone lines, gas pipelines, and transport systems - nearly all of which are privately owned-

G. Shanahan, Public Law Enforcement/Private Security: A New Partnership?, FBI L. Enforcement BuLl., Jan. 1990, at 18, 21:

[C]ooperation between public law enforcement and private security must continue and, if there is one area where public law enforcement and private security have worked cooperatively for joint advantage, it has been in the area of collection and dissemination of records. The ability of both public law enforcement and private security to amass large amounts of personal data about people's personal histories, employment records, etc., poses serious liability problems during an era that has seen severe restrictions placed on the use and release of such data.

142. The BLEA brought public police attention and support to an initiative by banks that required persons without accounts in a particular bank to place an inkless fingerprint on their checks before being allowed to cash them. Green, supra note 133, at 96-97.

143. Marx, supra note 135 , at 182.

144. Woody Baird, FedEx Guards Packages, Planes with Private Police, Orlando Sentinel, Feb. 28,2004 , at C2.

145. Gary Fields, FedEx Takes Direct Approach to Terrorism: Carrier Sets up Its Own Police Force, Gaining Seat on Regional Task Force Overseen by FBI, W ALL St. J., Oct. 9, 2003, at A4.

146. See id. ("Air carriers generally have a good relationship with the FBI [anyway] because many of the airlines' security personnel are former agents.").

147. Baird, supra note 144 , at C2.

148. Fields, supra note 145 , at A4. 
prompted increased calls for private-public partnerships. ${ }^{1+9}$ These concerns have led to the foundation of groups such as the 1,800 member InfraGuard network, permitting member corporations to receive information on threats to bridges and other parts of the national infrastructure before it is available to the general public. $^{150}$

Despite the fact that public agencies are involved in these alliances, there is no public regulation over the partnerships themselves. Nor are there any requirements that these partnerships measure the impact or success of their joint ventures. As a result, it will be nearly impossible, absent voluntary disclosure, to evaluate these emerging organizations.

\section{Special Tax-assessment Districts}

Beginning in the 1970s, cities like New York, Philadelphia, St. Louis, and Los Angeles experimented with a new form of partnership in special tax-assessment districts, sometimes referred to as business improvement districts. ${ }^{151}$ In these special districts, private property owners in physical proximity to one another (and typically in urban commercial areas) ${ }^{152}$ establish a formal association and agree to tax themselves, in excess of their normal obligations, to pay for additional collective services such as private police and sanitation workers. ${ }^{153}$ The property owners first pay the fees to the city, which then returns the money to the special district to pay for the increased services. By 1999, there were 1,200 business improvement districts in North America, with 150 to 200 in California and 34 in New York City alone. ${ }^{154}$

149. See Ralph Shrader \& James Woolsey, Comment: Business Must Be Involved in Security Planning, Fin. Times, Jan. 16, 2004, at 15 (advocating partnerships). Woolsey is the former director of the Central Intelligence Agency.

150. See Profile: Private Companies Being Warned of Possible Terrorist Threats Before It's Made Public (Minnesota Public Radio: Marketplace broadcast Nov. 6, 2001); Critical Infrastructure Protection: Hearing Before S. Comm. on Governmental Affairs, 106th Cong. (2001) (statement of Jamie S. Gorelick, Vice Chair, Fannie Mae).

151. See, e.g., Joseph Mokwa \& Terrence W. Stoehner, Private Security Arches over St. Louis, SecuRITY MGMT., Sept. 1995, at 94 (describing operation of St. Louis's business improvement district (BID)).

152. Not all specially taxed districts include primarily commercial property owners. See, e.g., James F. Pastor, The Privatization of Police in America: An Analysis and Case Study 101 63 (2003) (conducting empirical study of Marquette Park Special Services Area, a special taxassessment district for a residential neighborhood in Chicago).

153. See Marla Dickerson, Suit Challenges Private Security Controls, L.A. Times, Nov. 17, 1999, at $\mathrm{Cl}$.

154. Id.; Mark S. Davies, Business Improvement Districts, 52 W ASH. U. J. URB. \& Contemp. L. 187, 192 (1997) (counting thirty-four BIDS as of 1996). 
An example of one such partnership is the special Center City District (CCD) in Philadelphia, established in $1991 .{ }^{155}$ The 2,087 property owners within the District, representing the city's highest concentration of hotels, stores, banks, and office buildings, pay a 5 percent property tax surcharge. This pays for the employment of forty-five to fifty private patrol officers. The CCD private police, who carry no weapons and who do not possess peace officer powers, patrol the district in "beats." The Philadelphia Police Department receives no special funds from the District but nevertheless has contributed sixty additional public officer posts to the District. Both groups of police work out of the same police substation located within the district. Thomas Seamon, deputy police commissioner of the Philadelphia Police Department, credited this "merging of public police and private security" with a 6-percent decrease in crime in a twelvemonth period. ${ }^{156}$

\section{The Changed Discourse on Private Policing}

By the end of the twentieth century, private policing had gained new respectability from the government and the public police. To be sure, there remained dissenting views that were less sanguine about the role of private policing. In 1971, the Berkeley Center for Research and Justice raised doubts that private police would "provide any lasting solution to the fear and insecurity that have come to dominate U.S. cities," and further suggested that security guard employment could only exacerbate already strained urban race relations. ${ }^{157}$ Civil liberties groups like the American Civil Liberties Union have consistently questioned the desirability of private police employment from their use in strikebreaking to the present day. ${ }^{158}$ And, their popularity notwithstanding, a number of business improvement districts have faced lawsuits accusing their

155. See Thomas M. Seamon, Private Forces for Public Good, Security Momt., Sept. 1995, at 92; Greene et al., supra note 126, at 13-15.

156. Seamon, supra note 155 , at 92.

157. Ctr. for Research on Criminal Justice, The Iron Fist and The Velvet Glove 157 (1977).

158. See Opposes Private Police, N. Y. Times, Feb. 24, 1930, at 13 (reporting state-wide campaign in Pennsylvania by the ACLU to "abolish the private police system"); Ford Police in Rackets, Accusation, L.A. Times, Apr. 11, 1932, at 2 (describing letter from ACLU to Henry Ford alleging its private police "connected with gangsters and racketeers"); Ralph Blumenthal, Private Guards Cooperate in Public Policing, N.Y. Trmes, July 13, 1993, at B1 (citing New York Civil Liberties Union as questioning accountability of private police). 
private police forces of illegal conduct, including the alleged harassment of the homeless. ${ }^{159}$

Yet the shift in conventional wisdom about private policing was undeniable. What had changed was the balance of public views. Conspicuously missing from the debate were any of the fundamental criticisms of private policing characterized by the La Follette or Homestead investigations. ${ }^{160}$ Absent were questions about the "delegation of the sovereign power of the State to private hands." ${ }^{101}$ In contemporary discussions, private police do not by their very nature threaten civil liberties or challenge the right (or duty) of the state to provide policing services. Through their exhortations and reinterpretations, the reports that first appeared in the 1970s played an important role in relegating the perception of opprobrious conduct by private police to the past.

That privately paid protection of life and property could enhance the protection provided by the state had been suggested even during the most intense periods of criticism against the private police in the 1890 s and 1930 s. $^{162}$ So why did the partnership model, building upon that long-standing argument, hold such appeal in the last quarter of the twentieth century? One reason may be found in a larger contemporary debate over the responsibility and capability of government to control crime: A crisis in what David Garland terms the "myth of sovereign crime control"163 - the implicit promise of modern governments for "control of crime and the protection of citizens."

159. See Dickerson, supra note 153 (describing class action lawsuit against three security companies and BIDs employing them); Terry Pristin, For Improvement Districts, Restored Alliance with City, N.Y. Times, Feb. 18, 2002, at B1, B3 (describing the alleged assault of homeless people at the Grand Central Partnership in 1995).

160. See Shearing, supra note 7, at 419, reprinted in Modern Policinc, supra note 7, at 419.

161. William T. Martin, Editorial, Industrial Police Stir Pennsylvania, N.Y. TImes, Feb. 1, 1931, at 58.

162. See, e.g., Bankers' Private Police, N.Y. Times, June 17, 1900, at 11 ("Banks, bankers, and trust companies could not with safety wholly depend on the uniformed police and the Headquarters and precinct Detective Sergeants, detective officers, and special officers for protection against the 'dangerous classes."').

163. David Garland, The Limits of the Sovereign State: Strategies of Crime Control in Contemporary Society, 36 Brit. J. Criminology 445, 448 (1996); see also Adam Crawford, The Local Governance of CRIME 23-24 (1997) (discussing the development of the public monopoly over crime control).

164. Garland, supra note 163, at 448; see also CRAwFord, supra note 163, at 23 ("IBeginning in the 19 th century, $t$ ]he responsibility for policing was firmly located in the state... Communities and the public were defined as recipients of a service. This conception has remained dominant, and was supported and extended by the establishment of the welfare state in the twentieth century."). 
The second half of the twentieth century saw, as I have discussed elsewhere, ${ }^{165}$ many Western democracies caught in a dilemma. Faced with persistently high crime rates, public officials responsible for criminal law policies and expenditures saw the need to qualify a fundamental and implicit promise of modern government: to guarantee safety and security to its citizens. That qualification took two approaches. One took the form of careful but deliberate statements that government could not be expected alone to guarantee protection from crime. ${ }^{1\left({ }^{6}\right)}$ Another was the transformation of a longstanding skepticism toward private policing into public approval and the encouragement of partnerships.

These public-private partnerships, now unquestionably an important crime control approach in the United States, rest upon assumptions whose implications have not yet been fully explored. First, it is presumed that partnerships share common objectives. ${ }^{16 \tau}$ Private police agencies, however, can play a significant role in shaping the definition and scope of the projects they wish to target with public aid.

Consider the advocacy of the International AntiCounterfeiting Coalition, Inc. (IACC), an organization representing "exclusively the interests of companies concerned with IP [intellectual property] enforcement," 168 which presented testimony to the International Relations Committee of the House of Representatives. Concerned that product counterfeiting and piracy constituted "very low law enforcement priorities after September 11, 2001," IACC president Timothy Trainer argued that counterfeiting often provided sources of funding to terrorists. ${ }^{169}$ In the organization's view, public support for the IACC's goals of policing counterfeit jeans and handbags will "aid in the battle against terrorism and also

165. Joh, supra note 4 , at 68 .

166. See id. (citing pronouncements by former director of National Institute of Justice and the British Home Office).

167. See, e.g., Pending Crime Bill: Hearing on H.R. 2641, H.R. 2803, and H.R. 2996 Before H. Comm. on the Judiciary, 104th Cong. (1996) (statement of Rep. Bill McCollum, Chairman, H. Subcomm. on the Judiciary) (stating that with regard to proposed bill on partnerships, "[p]ublic law enforcement and the private security industry work toward the same goals").

168. Int'l AntiCounterfeitinc Coalition, Inc., Submission to the United States Trade RePresentative: SPECial 301 Recommendarions 2 (2005), available at http://www.iacc.org/2005301.pdf.

169. Counterfeited Goods Funding Terrorism: Hearing Before the H. Int'l Relations Comm., 108th Cong. (2003) (statement of Timothy P. Trainer, President, Int'l AntiCounterfeiting Coalition, Inc.). 
enhance our national economic security." ${ }^{" 70}$ By redefining its own interests and persuading lawmakers that these interests are public ones, the IACC presented a case for public-private pursuit of the "public interest." Because public resources are finite, the characterization of some private police objectives as "public" ones ultimately means shifting attention and resources away from some concerns and toward others. While some substantive goals of private and public police may coincide, it would surely be a mistake to characterize their goals as identical. ${ }^{171}$

Another assumption underlying these partnerships is that mutual benefit accrues to the "communities" served by private and public forces. ${ }^{172}$ Private policing, in the view of some of its advocates, represents true community policing: safety and protection on demand. ${ }^{173}$ This characterization, however, obscures what can be very different instantiations of community. What is more, such proposals ignore the fact that community itself-its membership and very definition-is often a contested and fluid concept. A fundamental premise of public policing is "policing by consent"-accountability to the very people for whom the police provide protection. Privately policed "communities" often have a sponsor (the employer) distinct from the policed group (shoppers, students, office workers). To be sure, to the extent that a private policing community incorporates legalistic values, the policed group will be able to funnel complaints and opinions that will affect

170. See Int'l AntiCounterfeiting Coalition, Inc., The Negative Consequences of International Intellectual Property Theft: Economic Harm, Threats to the Public Health and Safety, and Links to Organized Crime and Terrorist Organizations 36 (2005), htep:// www.iacc.org/WhitePaper.pdf. Prominently featured in this "white paper" on terrorism and counterfeiting are reports that those who bombed the World Trade Center in 1993 had financed their activities with counterfeit textile sales from a store in New York City. See id. at 20 (citing news articles).

171. Some courts have refused to recognize private police as state actors precisely for this reason. See, e.g., Waters v. State, 575 A.2d 1244, 1247 (Md. 1990) (observing that the "private status lof security guards] is not altered because their interest in protecting property coincides with the public's interests in preventing crime generally").

172. See, e.g., Operation Cooperation, supra note 131 , at 3 ("Community policing, with its call to establish partnerships, requires cooperative efforts (including partnerships with "corporate citizens'), and private security is a natural partner.").

173. See, e.g., James J. Vardalis, Privatization of Public Police: Houston, Texas, 3 Security J. 210, 211 (1992) (arguing that the private police officer "recognizes the importance of establishing positive relationships with the consumers of the service and develops innovative approaches to community problems. In contrast [to] the public police, [who] are paid through the compilation of public taxes and are, therefore, answerable to every business and citizen in the city but are not accountable to them."). 
the nature of private policing. Universities offer a good example. Yet many privately policed places are poor analogues for the state-citizen relationship, and the number of these "commercial communities" is considerable.

My discussion of these two assumptions is only a preliminary one, and their resolution will require careful consideration over time, as partnerships become ever more popular. What is striking, however, is that even in embryonic form, these concerns hardly register in discussions about partnerships, which, as the prior sections suggest, are typically presented with unalloyed enthusiasm.

And it is clear that private police have assumed an even greater importance in the post-9/11 world than would have been projected even in the early 1990s. President Bush's 2003 National Strategy for the Physical Protection of Critical Infrastructure and Key Assets, for example, identifies private security guards as "an important source of protection for critical facilities." 174 Because much of the nation's "critical infrastructure"-including its energy producers, banking and finance operations, and transportation systems-are privately owned, private police are "viewed by many," including the Bush Administration, "as both a vital element of terror deterrence and the first line of response to terrorist attacks." 175 The states are equally supportive of training private police as "private counterterrorism agents." 176 Yet, as recently as November of 2004, a Congressional Research Service Report observed that "[q]uestions remain ... about ... the appropriate role of the federal government with respect to [private police] protecting critical infrastructure." 177

\section{Conclusion}

Contemporary appeals to partnership between private and public police are striking because they harbor little of the deep-seated suspicion directed against private police in the period after the Civil War and until the Cold War. Yet these police filled real needs. As U.S. cities slowly established public police departments in the nineteenth century, people relied upon private detectives and pa-

174. The White House, supra note 5, at 29.

175. Paul W. Parfomak, Guarding america: Security Guards and U.S. Critical Infrastructure Protection CRS-1 (2004).

176. Steve Geissinger, Anti-Terrorism Training Set for Security Guards - Goal Is to Recruit 500,000 Private Agents, Daily News (Los Angeles), Aug. 2, 2005, at N4.

177. Parfomak, supra note 175 , at CRS-25. 
trols to fill in perceived shortcomings of the new public police. In rural areas and the Western frontier, private police were sometimes the only option.

Private police involvement in labor struggles, however, provoked fears that privately paid forces could threaten the civil rights of workers, specifically, and the right (or obligation) of government to provide protection, generally. Congressional investigations spanning a period of nearly fifty years raised questions about the proper role of private police in society that were never fully resolved.

Critical scrutiny of private policing by the federal government disappeared after 1950, but not because any of these matters had been settled. In the 1970s, moreover, concerns about private policing gave way to a new language of partnership. In particular, reports commissioned by the federal government advocated the creation of formal relationships between private and public police. Initially reluctant, public police departments eventually chimed in with their support. As a result, today there are numerous formal relationships established between private and public police across the country, and the language of partnership permeates discussions about public police reform. Fundamental questions about the appropriate role of private police in society have disappeared.

History, however, teaches an important lesson. The enormous and largely unregulated private police industry in this country has flourished both by public encouragement in the form of policy statements and disengagement by failure to regulate. In both senses, private policing is shaped by the state, and consequently, deserves much more attention as an institution not wholly private, but public as well. 
